\title{
WOMAN, BODY AND VIRTUAL SPACE: A CRITICAL STUDY OF MANJULA PADMANABHAN'S PLAY HARVEST
}

\author{
Rachana Pandey \\ Department of English, Vasanta College for Women, Rajghat Fort, Varanasi, UP, India
}

\begin{abstract}
The present paper explores the relationship between gender and virtual space and studies how virtual space reproduces the gendered relations of power. Manjula Padmanabhan's play Harvest (1998) locates the female body in different positions in the real and virtual spaces. Technology rather confirms the existing gendered meanings assigned to the human body as it is shaped by the particular social and cultural patterns. In the play, Ginni is a virtual figure who controls Om, Jaya and their family through a virtual device called the Contact Module. Gender swapping of virtual Ginni/Virgil suggests not a denial of gender but the assertion of it. The virtual space does not liberate individuals from gendered bodies but emphasizes the gender differences, objectifies the body and confirms the binary of man/woman by projecting them into animated double figures. Manjula Padmanabhan, in the play, presents a frightening vision of a futuristic, technologically advanced world with gender imbalance against the popular images of romantic, fancy, beautified and easy going virtual world. In the given context, the paper analyses the idea that a virtual body is a cultural entity and explains how the idea of human body becomes a technological construction. The research is a textual study and analytical and descriptive methods are applied to it.
\end{abstract}

Keywords: Body, gender, virtual space, technology

\section{Introduction}

Gender is not only a social and cultural construct but a technological construct as well. Gender becomes a deliberate choice in the virtual space which not only enables human beings but disables, manipulates and negatively affects the familial and larger social system. The assertions of gender in virtual space have greater consequence which cannot be perceived by common (i.e. technologically illiterate) Third World people. In her play Harvest, Manjula Padmanabhan presents a frightening vision of a futuristic, technologically advance world against the popular images of romantic, fancy, beautified and easy going virtual world. The sense of future brings the sense of uncertainty as it not only includes hope, faith, dreams but risk and fear as well. The play Harvest deals with the harm of the emerging organ transplant industry, resulting in the commoditization of third world bodies and cases of abuse. It portrays a dystopian world where men and women from middle and lower class are either dragged into prostitution or forced to sell their body organs due to the state of poverty and unemployment. In the play, a virtual body from a developed country controls and subordinates real bodies who are ready to get exploited in order to find their basic needs. The paper locates body and gender identities in different positions and analyses the effect of virtual presence and technological advancement on them. Harvest was awarded the Onassis International Prize for Theatrical Plays in 1997.

The body is a product (cultural) and also a process. Human experiences and perceptions are mediated through their body. A cultural body is a manifestation of the inner mind (experiencing through the body), which is yet again a manifestation of the society outside to which it belongs. It was acknowledged late that "our physicality is the very means by which we define our existence as social beings" (Srivastava, 2013, pp.57). Arthur Brittan talks about in the context of masculine identity construction whereas, as it suggests, the idea applies to other genders also. He wrote, "that in inspecting myself and coming to the conclusion I am a man, I am not simply replicating automatically what everybody else has told and taught me about men, I am also accomplishing or 
doing 'maleness'. Every time I see myself as a man I am doing 'identity work' ” (Brittan, 1989, pp.36). 'Identity work' is exhibited in greater ways in the virtual space of advanced media and technologies and making, producing and establishing images becomes an everyday affair that too unstable and dangerously fragile in nature.

The ideas of making and producing are crucial to the study of body and gender identities. The fragile gender (feminine, in the context) identities are created through technology and reinforced through enactment. Isabelle Coy-Dibley quotes Susan Bordo (2003) who wrote that digital modification of images means that we are being educated to shift our perception of what a normal woman's body looks like, so that we see our own bodies as wanting because they do not match an unrealistic, polished, slimmed, and smoothed ideal much like the image of Ginni created by Virgil. It was only Jaya who could understand the danger of the situation and questions the alluring and monitoring practice of Contact Module (through Ginni) as Virgil says to Jaya, "For every fish, a dish" (Padmanabhan, 1998, p.95). When Guards enter into her house for the first time to fix the Contact module, Jaya gets infuriated over Guards mechanical manner as she asks them not to change the order of her house, “Don't you understand what I'm saying? Are you a machine? Answer me! (p.14-15). Virgil (from a First World country) projects a sensual image of a woman through Ginni to tempt Om and Jeetu. The presence of Ginni, a young white female animated figure, talking through the Contact Module (Mephistophelian figure) brought drastic changes in their family relationships. When MA, who is an old woman, saw Ginni through Contact Module for the first time, she could not understand how a human body can come through a small box as she said, "I can't understand a word of what that thing is saying! Is it a man or a woman? (p. 27). Ginni/Virgil provides a well-furnished living space to everyone (called 'fancy prison' by Jeetu) in Om's family in order to purchase Om's body organs, manipulate Jaya's body and exploit other family members too. In fact, Virgil also manipulates the gaze of every family member in Om's house in order to get his purpose served.

At the beginning of the play, Om explains the nature of his job to his mother but he fails to make her understand since no job pays for sitting at home idly. In Act I Scene One, the conversation between the two is as follows:

MA. But what is the work? The pay packet? The hours?

OM. (looking distracted) I -- I'll be in the house ...

MA. What?! All the time?

JAYA. (staring intensely at him) ... You don't really know what it's going to be like, do you?

MA. What kind of job pays a man to sit at home? (Padmanabhan, 1998, p.13)

Without revealing his work (as Organ donor) Om informs them that they will be monitored carefully. He says, "Not just us but our . . . lives. To remain employed, we have to keep ourselves exactly as they tell us" (Padmanabhan, 1998, p.13). MA, who is still unable to understand Om's job, she asks, "Tell me again: all you have to do is to sit at home and stay healthy?" (p.13). It was Jaya who uncovered the ugly reality as she told MA, “All that remains to be known is which part of you's been given away! (p.21).

\section{Woman, Body and Identity Construction}

Simone De Beauvoir's statement that a woman is not born a woman but becomes one clearly indicates towards the constructive nature of gender or gender determinism. The idea of 'woman' is a socio-cultural construct and it has also been the product of history, literature - textual formation. Women are not only the product but the participants and producer of narratives of female spaces. Though contemporary feminist scholars try to avoid 
"fixing" woman and the word become contextual having multiple connotations. Judith Butler's significant theory of gender as performative, gender as 'drag' and gender as being repeated stylization of the body has challenged the notion of originality and naturalness of gender identity. Gender roles are fluid and negotiable and never fixed. Gender shapes a male as the masculine man and a female as the feminine. Butler wrote, "gender is a copy with no original" (quoted in Halberstam, 2012, p.17).

A woman's body has always been devalued and considered vulnerable. Ironically, even in the ultra-modern world of technology, projected by Padmanabhan in the play Harvest, the woman is demanded to perform her socially assigned and biologically non-obligatory role of childbearing to create the future generation of donors in the Third World. A male virtual figure Virgil told to Jaya that it is her destiny as a woman (Padmanabhan, 1998, p.97). He tells Jaya the duty of a woman which is to become a childbearing body. Because in the world of Virgil, people have lost the art of childbearing due to advancements and long, competitive life, he targets Jaya as a laboring body to produce future generation. Jaya's female reproductive body is commodified and considered as saleable to which she resisted and denied. Hence, the animated figure of Virgil who is visible only on screen, explains to Jaya (because she rebels against him),

VIRGIL. We look for young men's bodies to live in and young women's bodies in which to sow their children - (Padmanabhan, 1998, p.96)

\section{Virtuality}

Every time Guards of InterPlanta Services enter into Jaya's home, they mechanically repeat, "Thank you for your cooperation and valuable time! I and my colleagues deeply appreciate the contribution you are about to make towards creating a healthier, happier and longer-lived world!" (Padmanabhan, 1998, p.19). It is sarcasm, highlighting the centralization of power (which has been defined as 'technological' in the play in a futuristic sense) in the First World countries and the purpose of InterPlanta Services in to maintain the health and lives of the dominant world and not the whole.

New technologies have generated multiple utopian and dystopian fantasies but such fantasies are, as Constance Penley and Andrew Ross argued, "an expression of real popular needs and desires" (quoted in Wolmark, 2003, p.215). Against the popular image of romantic, fancy, beautified and easy going world, Manjula Padmanabhan allegorises and presents a frightening vision of a futuristic, technologically advanced world. Here, in the play, a virtual body (Ginni, a female figure) from Virginia is controlling real, thinking and breathing bodies of the disadvantaged section of India, a third world country. The virtual figure provides Virgil with a tool to have power over the others and without even crossing the boundary of his home space in his actual body he crosses the boundary of nation and controls and manipulates the lives of the people who were living in the other part of the world. Ginni/Virgil who belongs to the first world country is in the role of receiver, buyer and hence, privileged. In exchange for the life support that he offers to the poor sections of the third world, he purchases a body, health, youth and long life for him. The contact module, a device which looks like a globe, hanging from the ceiling, was the decision maker which controls Om and his family. Ginni commands Om to smile always for the good health of his body organs. Ginni who is a computer-animated image of a beautiful young white woman (a body that was never actually there) made Om and Jeetu follow her commands blindly and mesmerised Ma to appreciate her beauty by calling her an angel.

Virgil told to Jaya that Ginni is not real only after successfully completing body transplant. He plays game with Om and Jeetu to lure them as he says to Jaya, "For every fish, a dish" (Padmanabhan, 1998, p.95). Virgil chose a gender (as Ginni, a female) for performance in front of Om and his family which was a strategically made choice. Virgil never comes in his real body but always in desirable form, manipulated other's gaze to serve his purpose. It is not any woman in real who persuades Om and Jeetu to make them agree for transplants but a man with white male gaze behind Ginni's face, a beautified image of a woman. Ginni's presence makes Jaya uneasy. Laura Mulvey wrote, "Women are constantly confronted with their image in one form or another ... Yet, in a 
real sense, women are not there at all. The parade has nothing to do with woman, everything to do with man ..." (quoted in Pollock, 2003, p.180). Virgil chose to become Ginni for Om and Jeetu and he changes into Jeetu's body and came in his skin through the Contact Module to persuade Jaya though he fails in Jaya's case.

Ginni/Virgil's body is present only on the screen throughout the play. Ginni/Virgil is a virtual figure in the position of the subject, demanding obedience from the others. It is not only a neutral, genderless voice but a gendered figure. It is not a denial of gender but the assertion of gender through Ginni. The fluidity of gender identity has both positive and negative connotations and the visual world can create a non-human, artificial gendered figure, an illusion which results in negative. Through Ginni, Virgil chose a gender (Ginni, a female figure) to perform deliberately, to persuade and control Om and later, Jeetu also. The act of choosing a gender to perform, provided by techo-space and virtual world does not actually liberate individuals from gendered bodies rather it reconstructs the gender differences, objectifies the body, confirms the idea of man and woman in an essentialist sense by projecting it into animated figure. Anne Balsamo points out that techo-body is also the cultural construction and it "allows normative gender identity to be reinscribed, despite much vaunted promises to the contrary" (Wolmark, 2003, p.228).

The control of Ginni over the family members compels them to live lifeless lives as Jaya mentions that "It's not really a life any more. We're just spare parts in someone else's garage -" (Padmanabhan, 1998, p.34). The restricted, machinery life makes Om and Ma insensitive and mechanical. They obey Ginni blindly, for example, Om mentions, "Ginni says - the curse of the Donor World is sentimentality" to explain Jaya about Jeetu's condition (p.49). He forbids Jaya to risk her own skin by taking care of Jeetu who came back sick after spending a few days on the streets. The donor's family was not treated as human beings but as body parts which needs to be protected to make use of it as Jaya argued that Ginni spends money on them and cares for them "just as much as she cares about the chicken she eats for dinner" only in desire of the best when it gets to her table finally (p.50).

Jeetu expresses his disgust for the changed interior of the room by calling it a "fancy prison" (Padmanabhan, 1998, p.59). When Jeetu's eyes are transplanted his condition becomes pathetic as he is not able to see, to sleep, dream or even to cry. Jeetu loses his eyes and he could see only those images that were projected into his mind directly by Ginni/Virgil. He not only lost his eyes but his vision towards life, his pride and his sense of freedom. When Jaya accuse Virgil of the death of Jeetu whose body organs are transplanted into the old body of Virgil, he contemptuously defined death in two ways: body-death and self-death (93). Jeetu has lost both as he lost his self, his freedom to take his decisions and he also lost his body (transplanted) due to Virgil's greed for youth, health and long life. Instead of getting assimilated, Virgil's hybrid body after the transplants kept the sense of self and other, the binary differences between first world-third world, donor-buyer intact. It makes Virgil a Mephistophelian figure in the play that not only controls other's body and self but also takes control over their death. He says to Jaya that she cannot choose death for herself since the food he has provided contains antisuicide drugs. Sujatha Moni wrote that plucking out of Jeetu's eyes symbolises the "removal of the indigenous gaze" and replacing it with unfamiliar images according to Virgil's wish (7). Hence, there was no escape and no choice for the third world underprivileged bodies, not even death. The play represents the world of advanced technology and science with the cultural and gendered practices same as existing through in different and more hideous manner.

\section{Technology as Enabling}

- Gender becomes a choice which is liberating in a positive sense.

- A free play of identity is possible through virtual space.

- Technology also allows the expression of multiple subjectivities (subjectivity which explains 'who am I' - context specific) 
- Spatial expansion and networking become easy.

\section{Technology as Disabling}

- Gender determinism increases as it essentializes male and female into binary category (as explained through the textual reading of the play Harvest)

- The portrayal of woman, stereotyping and misrepresentation become a norm: the play Harvest in context

- Non-moralistic

- Technology as an instructor is dangerous (since it works in a fixed mode) as in the case of Ginni

To conclude, it must be added that every coin has two sides and in the language of a postmodernist, multiple sides hence, it is the 'technology' which creates the problem but the use and handling of technology which needs to be sensitized. Further, technology should work to create an alternative friendly space since a complete elimination of technology cannot be a solution for the world. Meaning is always in process, in the making so the scope for a positive transformation can take place through right efforts and actions as it is "the fact that human social existence is forever in the process of being made and remade through actions upon and within collective life" (Srivastava, 2013, p.53).

\section{References}

Brittan, Arthur, 1989, Masculinity and Power. Print ed. UK: Basil Blackwell.

Buchmuller, Sandra, Gesche Joost and Rosan Chow, 2007, Body Extensions and Representations within Disembodied Virtual Spaces. IASDR07, pp. 1-34.

Available

at: https://www.sd.polyu.edu.hk/iasdr/proceeding/papers/Body\%20extensions\%20and\%20representations\%20withi n\%20disembodied\%20virtual\%20spaces.pdf. [Accessed 17 January 2018].

Butler, Judith, 1990, Gender Trouble: Feminism and the Subversion of Identity. Print ed. New York: Routledge. Butler, Judith, 1993, Bodies That Matter. Print ed. New York: Routledge.

Coy-Dibley, Isabelle, 2016, "Digitized Dysmorphia" of the female body: the re/disfigurement of the image. Palgrave Communications, Issue 2.

Available at: https://www.nature.com/articles/palcomms201640. [Accessed 30 January 2018].

de Beauvoir, Simone, 1953, The Second Sex. London: Jonathan Cape. [Online]

Available at: http://hagocrat.files.wordpress.com/2012/06/de-beauvoir-simone-second-sex.pdf.

[Accessed 5 August 2013].

Halberstam, Judith, 2012, Female Masculinity. Print ed. New Delhi: Zubaan, an imprint of Kali for Women.

Padmanabhan, Manjula, 1998, Harvest. Print ed. New Delhi: Kali for Women.

Pollock, Griselda, 2003, The Visual. In: Mary Eagleton ed. A Concise Companion to Feminist Theory. USA: Blackwell Publishing, pp. 173-194.

Srivastava, Sanjaya, 2013. Performative Bodies. In: Gendered Bodies and Sexualities. New Delhi: IGNOU, pp. 53-68.

Wolmark, Jenny, 2003, Cyberculture. In: Mary Eagleton ed. A Concise Companion to Feminist Theory. USA: Blackwell Publishing, pp. 215-235. 